\author{
Current Research in Agricultural Sciences \\ 2022 Vol. 9, No. 1, pp. 13-21. \\ $\operatorname{ISSN}(e): 2312-6418$ \\ $\operatorname{ISSN}(p): 2313-3716$ \\ DOI: $10.18488 /$ cras.v9i1.2915 \\ (C) 2022 Conscientia Beam. All Rights Reserved. \\ check for
updates
}

\title{
EFFECTS OF DIFFERENT RATES OF WOOD ASH ON THE GROWTH AND YIELD OF CARROT (DAUCUS CAROTA) IN AWKA, SOUTH EASTERN NIGERIA
}
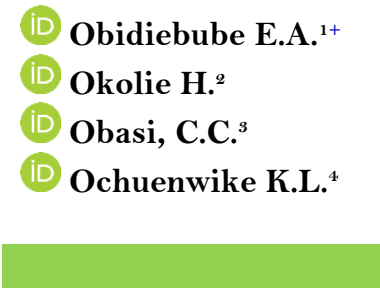

\author{
${ }^{1,2, s, 4}$ Department of Crop Science and Horticulture, Faculty of Agriculture, \\ Nnamdi Azikiwe University, Awka, Nigeria. \\ 'Email: ae.obidiebube@unuzik.edu.ng Tel: +2348033230276 \\ -Email: h.okolie@unizik.edu.ng Tel: +2348032596944 \\ ${ }^{3}$ Email:cc.obasi@unik.edu.ng.Tel: +2348032558331 \\ ${ }^{4}$ Email: ochuenwikekelechi@gmail.com Tel: +2349016007431
}

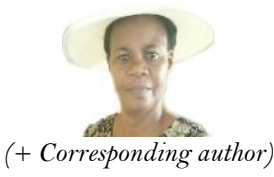

\section{Article History}

Received: 6 December 2021

Revised: 10 January 2022

Accepted: 24 January 2022

Published: 1 February 2022

\section{Keywords}

Replication

Experiment

Field

Pot

Significant

Yield

Varieties.
A 2 by 4 experiment laid out in RCBD was conducted at Crop science and Horticulture agricultural farm, Nnamdi Azikiwe University, Awka, Nigeria. The experiments were conducted from June to September 2020 to study the effects of different rates (0.0, 0.1,0.2,0.3 t/ha) of wood ash on the growth and yields of carrot varieties in Awka South Eastern Nigeria, the experiment was carried out on pots and beds. It was observed that treatment $0.3 \mathrm{t} /$ ha performed significantly better in most of the assessed parameters both on growth and yields such as: plant height, marketable yield, root diameter, whole plant biomass, root length, total yield and harvest index. While ot/ha performed lowest in the growth and yield of carrot varieties for the bed experiment. On pot experiment, $0.2 t /$ ha of wood ash gave highest result both on growth and yield parameters (harvest index, leaf fresh weight, marketable yield, root diameter, root fresh weight, root length, whole plant biomass, and total yield in the pot experiment). Then with $0.3 \mathrm{t} / \mathrm{ha}$ of wood ash and carrotte touchon variety was the best combination for carrot yield on bed experiment. Generally, carrote touchon performed better than tonchon France carrot variety both in the pot and field. Field experiment was also the best experiment than pot experiment.

Contribution/Originality: This study is one of very few studies which have investigated how carrot responds to different rates of wood ash as growth promoter both in bed and pots.

\section{INTRODUCTION}

Carrot (Daucus carota) a biennal herbaceous specie is a member of the Apiacea family [1]. It belongs to the same family as parsnip, celery, parley, dill and fenel [2].The cultivated carrot are mainly classified into eastern carrots and western carrots based on pigmentation [3]. The Eastern carrots are thought to originate from Afghanistan, while the origin of the Western carrot is still uncertain [1]. The roots of most western carrot are: orange, red or white. The leaves of western carrots are highly dissected and the roots are unbranched [3].The roots of eastern carrots are yellow and some are purple; They have slightly dissected leafs and branched roots; The orange carrots are popular and more widely cultivated in the world; Western carrots are always cylindrical or tapered cylindrical in shape and have less pubescent leafs [1]. Eastern carrots always have thicker, shorter, narrow, conical roots, have pubescent leaves and flower early [1]. Like many other coloured vegetables, carrot is a gold mine of antioxidants; they have been shown to have inhibition mutagenesis activity contributing to decrease risk of some cancers; Carrot also exerts anti carcinogenic activities, reduce inflammatory insult, and moderate immune responses [4]. Among 39 fruits and vegetables, carrots have been ranked 10th in nutritional value; Carrot is a good source of dietary fiber and of the trace 
mineral molybdenum, rarely found in many vegetables [3]. Comparing to other vegetables, carrots can provide in the human diet significant amount of vitamin A due to the high bioavailability of carrot carotenoids [3]. Also, carrot is particularly rich in carotene (pro- vitamin A) [5].

Wood ash is the residue powder left after the combustion of wood, such as burning wood in home fire place or an industrial power plant. It results from burning or gasifying wood and consists mainly of minerals that the trees have absorbed over their life time. Wood ash increases the $\mathrm{pH}, \mathrm{Ca}, \mathrm{Mg}, \mathrm{K}$ and $\mathrm{P}$ of a brunisol and luvisol but has little effect on their microbial activity and biomass [6]. A study in Alberta has shown that lime and wood ash increased microbial biomass and $\mathrm{C}$ mineralization, and changed the functional structure of bacterial communities in an acid agricultural soil [7]. Also, Wood ash has been used extensively in northern Europe to improve forest productivity and to curtail the cost of landfills [7].

Persistent over use of fertilizers to increase the crop yield has led to serious consequences on environment and human health. Carrot yield and nutritional quality are affected by the fertilizers applied and the varieties Win [8]. Adekayode and Olojugba [9] suggested that the increasingly high cost of mineral fertilizers and preferred economic disposal of wood ash had necessitated research in the use of wood ash to reduce the rate of fertilizer application for maize production [10] Scientists are now on look for alternatives of fertilizers which can substitute nutrients in soil without damaging the environment; this led to the use of wood ash in the experiment instead of chemical fertilizer. Due to the chemical composition of wood ash, it has been shown that ash can be used to raise $\mathrm{pH}$ in soils. Its content of many of the plant nutrients often limiting plant growth suggests that wood ash could also be useful as fertilizer; since the content of nitrogen is low, fertilization with only wood ash would not be sufficient for most crops [11]. Wood ash increased crop performance in production of crops such as Soybeans [12, 13] cassava [14], tomato and pepper [15], groundnut [16] and vegetables [17]. On other hand, the organic source of nutrients provide consistent and slow release of nutrients, maintain ideal C: $\mathrm{N}$ ratio, improve water holding capacity and microbial biomass of soil profile, without any adverse residual effects [18]. Although wood ash has been applied on crops at different rates, unfortunately, the Effect of Different Rates of Wood Ash on the Growth and Yield of carrot (Daucus carota) in Awka South - Eastern Nigeria has not been reported.

The objectives of the research were therefore to:

1. Determine the effects of wood ash on the growth and yield of carrot.

2. To identify the rate of wood ash that gives optimum yield on the production of carrot.

3. To compare the performances on the field and pots.

4. To compare the yields of the two cultivars.

\section{MATERIALS AND METHODS}

\subsection{Experimental Site Description}

This present experiment was carried out at the Department of Crop Science and Horticulture Research Farm, Nnamdi Azikiwe University, Awka, Anambra State Nigeria to study the Effect of Different Rates of Wood Ash on the Growth and Yield of carrot (Daucus carota) in Awka, South-Eastern Nigeria. Awka is characterized by tropical rainforest with temperature of $27^{\circ} \mathrm{C}-30^{\circ} \mathrm{C}$. The area is located between latitude $06^{\circ} 15^{1} \mathrm{~N}$ and longitude $07^{\circ} 08^{1} \mathrm{E}$, with an average rainfall of $1810.3 \mathrm{~mm}$ per annum. The bed and pot experiments were carried out in the raining season (June - September, 2020).

\subsection{Experimental Treatment and Experimental Design}

This research was carried out on beds and pots. For the bed and pot experiment, 2 factors were used: Factor $\mathrm{A}=$ Wood ash rates (0, 0.1, 0.2 and 0.3 tonnes $/$ ha); Factor $\mathrm{B}=2$ Carrot cultivars. The experiments were a $2 \times 4$ factorial experiment laid out in Randomized Complete Block Design (RCBD) with 4 replications. These varieties were sourced from a reputable dealer at Jos. The wood ash rates 0, 0.1, 0.2 and 0.3 tonnes / ha and two carrot cultivars listed above 
were used for the two experiments. The treatment combination for the bed and pots includes: Aotonne/ha+V1, Aotonne/ha+V2; Ao.1 tonnes/ha+V1; Ao.1tonnes/ha+V2, A0.2 tonnes/ha+V1, A 0.2tonnes/ha +V2, Ao.3tonnes /ha+V1, Ao.3tonnes/ha+V2.

\subsection{Bed and Pot Experiment Description}

The bed experiment was conducted to evaluate the effects of different rates of wood ash on the growth and yield of carrot in Awka, South- Eastern Nigeria. The field had a land area of $11.5 \mathrm{~m}$ by $5.5 \mathrm{~m}$ and a plot size of $1 \mathrm{~m} \times 1 \mathrm{~m}$, furrow spacing of $0.5 \mathrm{~m}$ along each plot and a $0.5 \mathrm{~m}$ pathway across each plot. Plant spacing of $20 \mathrm{~cm}$ by $30 \mathrm{~cm}$ was used. A total of 16 seeds were sown per bed. On the whole 32 beds were used for the bed experiment. The pot experiment was conducted to evaluate the effects of different rates of wood ash on the growth and yield of carrot in Awka, South- Eastern Nigeria. A total of 32 pots were used as in the field for the experiment and were perforated at four spots at the base and four spots by the side to ensure effective drainage and aeration. Top soil was collected from the Department of Crop Science and Horticulture Research Farm, Nnamdi Azikiwe University, Awka, Anambra State, Nigeria. The soil was air dried for three days to expose pests and some disease-causing organisms.

\subsection{Data Collection and Analysis}

Soil samples from $0-15 \mathrm{~cm}$ depth of the experimental site were taken by simple random sampling method in order to analyze the physicochemical properties of the soil at the start of the experiment. Ten sub-samples were randomly taken and mixed thoroughly to get a composite sample. The soil sample was then pretreated by air drying and passed through a $2 \mathrm{~mm}$ sieve before analysis. Wood ash was also sieved to remove unwanted particles and taken to the laboratory for analysis. Plant height was measured in centimeters $(\mathrm{cm})$ using a meter scale at 45,60 and 75 days after sowing (DAS) from the point of the attachment of the leaves to the root (ground level) up to the tip of the longest leaf. Number of leaves per sampled plant both for the bed and pot experiments was counted at 45, 60 and75 DAS. All the leaves of the plants were counted separately. Only the smallest young leaves at the growing point of the plant were excluded from the counting. The plant girths of sampled plants were recorded for the bed and pot experiments. A thread was placed at the base of each sample to measure its circumference and was placed on a meter rule. The plant girth was measured separately and recorded at 45, 60 and 75 DAS. The average diameter of the root was measured at the thickest portion of the root at harvest with the help of a slide caliper. The average length of the root was recorded in $\mathrm{cm}$ using a meter rule from the point of attachment of the leaves (proximal end) to the last point of the root (distal end) in each treatment combination. Total yield tonnes / ha was taken which consists of both good quality roots, branched, racked and rotten roots. The marketable yield of roots tonnes / ha which consisted of good quality roots other than branched, racked and rotten roots was measured. Thus: Marketable yield $=$ Gross yield - Non marketable yield of cracked, branched and rotten root. Number of harvested plants per bed and pot was also measured where three plants were harvested from each bed and pot. Harvest Index on fresh weight basis (\%) was collected by calculation using the formular below:

$$
\mathrm{HI}(\%)=\frac{\text { Rootweight }}{\text { Wholeplantbiomass }} \times \frac{100}{1}
$$

Table 1. Root uniformity indices and percentages.

\begin{tabular}{c|l|l}
\hline S/No & $\begin{array}{l}\text { Index } \\
\text { Description }\end{array}$ & Percentage of each Index \\
\hline 1 & Not Uniform & $<30 \%$ of the roots are similar in size and shape \\
\hline 2 & Fairly Uniform & $>30 \%<50 \%$ of the roots are similar in size and shape \\
\hline 3 & Uniform & $>50 \%<70 \%$ of the roots are similar in size and shape \\
\hline 4 & Very Uniform & $>70 \%<90 \%$ of the roots are similar in size and shape \\
\hline 5 & Highly Uniform & $>90 \%$ of the roots are similar in size and shape \\
\hline
\end{tabular}


Data were collected on root uniformity using visual examination of the roots following uniformity indices as shown Table 1.

For determining the significance between the treatment means and to draw valid conclusions, statistical analysis was made. The data from the various observations were subjected to statistical analysis by using Analysis of variance. The difference of the treatment means was tested using least significance difference at $5 \%$ level of significance and GENSAT version 12.1, year 2009 was used.

\section{RESULTS AND DISCUSSION}

\subsection{Soil and Wood Ash Physico-Chemical Properties of the Experimental Sites}

In Table 2, the available result indicated that potassium content in the wood ash was $4.99 \%$, nitrogen $0.025 \%$, organic carbon $1.26 \%$, organic matter $2.17 \%$ while $\mathrm{C}: \mathrm{N}$ was 45.00 . Other parameters were also observed in the same table. The result of analysis carried out with soil samples collected from the experimental site as presented in Table 3 , shows the physical and chemical soil properties. Based on the physical soil properties, there was high percentage of sand $(71.2 \%)$, clay was the least $(8.4 \%)$ while the textural class of the soil is sandy-loam. The chemical soil properties showed the percentage base saturation to be $80.23 \%$, organic matter $1.98 \%$, and Total No.97\%, other parameters were also determined.

Table 2. Wood ash chemical composition

\begin{tabular}{l|c}
\hline & Percentage (\%) \\
\hline $\mathrm{pH}$ in water & 10.69 \\
\hline Organic carbon (\%) & 1.26 \\
\hline Organic matter $(\%)$ & 2.17 \\
\hline Phosphorus & 0.317 \\
\hline $\mathrm{Ca}^{2+}$ & 19.58 \\
\hline $\mathrm{Mg}$ & 2.31 \\
\hline $\mathrm{N}(\%)$ & 0.025 \\
\hline $\mathrm{K}(\%)$ & 4.99 \\
\hline $\mathrm{C}: \mathrm{N}$ ratio & 45.00 \\
\hline
\end{tabular}

Table 3. Physical and chemical properties of the soil samples taken at $0-15 \mathrm{~cm}$ depth of the experimental site before planting.

\begin{tabular}{|c|c|}
\hline Soil Properties & Percentage (\%) \\
\hline \multicolumn{2}{|l|}{ Physical } \\
\hline Sand (\%) & 69.6 \\
\hline Silt (\%) & 22.0 \\
\hline Clay $(\%)$ & 8.4 \\
\hline Textural class & Sandy-loam (SL) \\
\hline \multicolumn{2}{|l|}{ Chemical } \\
\hline $\mathrm{pH}\left(\mathrm{H}_{2} \mathrm{O}\right)$ & 5.14 \\
\hline Total N (\%) & 0.97 \\
\hline Organic carbon (\%) & 1.14 \\
\hline Organic matter (\%) & 1.98 \\
\hline $\mathrm{Ca}($ Cmolkg-1) & 2.27 \\
\hline $\operatorname{Mg}($ Cmolkg-1) & 1.33 \\
\hline $\mathrm{K}($ Cmolkg-1) & 0.25 \\
\hline $\mathrm{Na}($ Cmolkg-1) & 0.12 \\
\hline $\mathrm{EA}($ Cmolkg-1) & 1.63 \\
\hline $\mathrm{ECEC} \mathrm{(Cmolkg-1)}$ & 4.97 \\
\hline $\mathrm{BS}(\%)$ & 80.23 \\
\hline Available P (mgkg-1) & 5.53 \\
\hline
\end{tabular}


3.2. Effects of Wood Ash Rates on the Growth Parameters of Carrot Varieties (Daucus carota) For the Bed and Pot Experiments

In Table 4, for the bed experiment, the growth parameters of carrot such as plant girth, leaf number and plant height increased with an increase in the application of wood ash rates, but then no significant difference was recorded. This agrees with the work of Ajala, et al. [19] who reported that the growth parameters such as plant height, number of leaves, leaf area, leaf area index, leaf length, stem diameter, number of flowers, number of pods, weight of plant and total biomass of amended maize-lima beans intercrop were significantly $(\mathrm{P}>0.05)$ increased by wood ash application, Lupwayi, et al. [7] reported that the tallest carrot plants were obtained with high levels of Shrawan, et al. [20] explained that increased potassium increased the number of leaves per plant and addition of ash to tilled and non- tilled soil increased cassava growth parameters (plant height, number of leafs and stem girth).

Table 4. Main effects and interactions of wood ash rates and variety on plant height and leaf number of carrot for bed experiment.

\begin{tabular}{|c|c|c|c|c|c|c|c|c|c|}
\hline \multirow{2}{*}{$\frac{\text { TRT }}{\text { W-Ash }}$} & \multicolumn{3}{|c|}{ P H } & \multicolumn{3}{|c|}{$\mathbf{L N}$} & \multicolumn{3}{|c|}{$P G$} \\
\hline & $\begin{array}{c}45 \\
\text { DAS }\end{array}$ & $\begin{array}{c}60 \\
\text { DAS }\end{array}$ & $\begin{array}{c}75 \\
\text { DAS }\end{array}$ & $\begin{array}{c}45 \\
\text { DAS }\end{array}$ & $\begin{array}{c}60 \\
\text { DAS }\end{array}$ & $\begin{array}{c}75 \\
\text { DAS }\end{array}$ & $\begin{array}{c}45 \\
\text { DAS }\end{array}$ & $\begin{array}{c}60 \\
\text { DAS }\end{array}$ & $\begin{array}{c}75 \\
\text { DAS }\end{array}$ \\
\hline To & 17.9 & 23.9 & 32.0 & 7.99 & 7.74 & 7.75 & 2.04 & 2.53 & 3.08 \\
\hline $\mathrm{T} 1$ & 14.8 & 22.2 & 28.5 & 5.12 & 6.36 & 7.87 & 2.18 & 2.68 & 3.12 \\
\hline $\mathrm{T} 2$ & 21.4 & 29.3 & 42.3 & 5.83 & 7.17 & 9.12 & 3.05 & 3.69 & 4.05 \\
\hline T3 & 19.8 & 31.2 & 42.4 & 4.83 & 7.42 & 9.80 & 3.07 & 3.57 & 4.04 \\
\hline LSD & 7.64 & 8.98 & 8.36 & 3.956 & 1.761 & 2.329 & 1.386 & 1.555 & 1.415 \\
\hline \multicolumn{10}{|l|}{ Variety } \\
\hline $\mathrm{V} 1$ & 19.6 & 25.9 & 35.0 & 5.93 & 6.97 & 8.21 & 2.86 & 3.20 & 3.82 \\
\hline $\mathrm{V} 2$ & 17.3 & 27.4 & 37.6 & 5.96 & 7.37 & 9.07 & 2.31 & 3.04 & 3.32 \\
\hline LSD & 5.40 & 6.35 & 5.91 & 2.797 & 1.245 & 1.647 & 0.980 & 1.100 & 1.001 \\
\hline \multicolumn{10}{|l|}{ INT } \\
\hline $\mathrm{To} \times \mathrm{V} 1$ & 18.9 & 24.1 & 30.1 & 8.31 & 7.06 & 7.25 & 2.43 & 2.91 & 3.41 \\
\hline $\mathrm{To} \times \mathrm{V}_{2}$ & 16.8 & 23.7 & 33.8 & 7.67 & 8.42 & 8.25 & 1.64 & 2.15 & 2.75 \\
\hline $\mathrm{T} 1 \times \mathrm{V}_{1}$ & 12.9 & 18.1 & 21.9 & 3.98 & 5.42 & 6.75 & 1.77 & 2.27 & 2.65 \\
\hline $\mathrm{T} 1 \times \mathrm{V}_{2}$ & 16.6 & 26.3 & 35.1 & 6.25 & 7.29 & 9.00 & 2.59 & 3.09 & 3.59 \\
\hline $\mathrm{T} 2 \times \mathrm{V}_{1}$ & 24.7 & 28.2 & 44.0 & 6.42 & 7.25 & 9.08 & 3.86 & 3.72 & 4.86 \\
\hline $\mathrm{T} 2 \times \mathrm{V}_{2}$ & 18.0 & 30.4 & 40.6 & 5.25 & 7.08 & 9.17 & 2.23 & 3.66 & 3.24 \\
\hline $\mathrm{T} 3 \times \mathrm{V}_{1}$ & 21.8 & 33.2 & 44.1 & 5.00 & 8.17 & 9.75 & 3.38 & 3.87 & 4.37 \\
\hline $\mathrm{T} 3 \times \mathrm{V} 2$ & 17.8 & 29.3 & 40.7 & 4.66 & 6.67 & 9.85 & 2.76 & 3.27 & 3.72 \\
\hline LSD & 10.81 & 12.71 & 11.82 & 5.594 & 2.490 & 3.294 & 1.960 & 2.200 & 2.001 \\
\hline
\end{tabular}

For the pot experiment Table 5, statistically, the main effects and interactions of wood ash rates and carrot varieties was not significantly different $(\mathrm{P}>0.05)$ as there was variations in growth parameters. This is not in line with the report of Lupwayi, et al. [7] that the vegetative growth, including plant height, number of leafs, fresh and dry weight of leafs were enhanced by higher potassium levels while control plants produced the lowest values.

\subsection{Effects and Interactions of Wood Ash Rates and Carrot Varieties on The Yield of Carrot (Daucus Carota) For the Bed and Pot Experiment}

\subsubsection{Bed Experiment}

With the result of the bed experiment in Table 6, statistically, the main effects and interactions of wood ash rates and carrot varieties were significantly different $(\mathrm{P}>0.05)$ on the yield parameters. This is in consonant with the study of Mbah and Nkpaji [21] who stated that when synthetic fertilizers were not applied, the use of wood ash produced significant effect on the yield of many crops, particularly maize; [7] reported that wood ash application generally improved soil properties which in turn enhanced maize grain yield. Wood ash increased performance in production of crops such as Soybeans [12,13] cassava [14, 22] tomato and pepper [15] groundnut [16, 23] and vegetables [17]. 
Table 5. Main effects and interactions of wood ash rates and variety on plant height and leaf number of carrot for pot experiment.

\begin{tabular}{|c|c|c|c|c|c|c|c|c|c|}
\hline \multirow{2}{*}{$\begin{array}{l}\text { TRT } \\
\text { W-Ash }\end{array}$} & \multicolumn{3}{|c|}{$\mathbf{P ~ H}$} & \multicolumn{3}{|c|}{ LN } & \multicolumn{3}{|c|}{ PG } \\
\hline & $\begin{array}{c}45 \\
\text { DAS }\end{array}$ & $\begin{array}{c}60 \\
\text { DAS }\end{array}$ & $\begin{array}{c}75 \\
\text { DAS }\end{array}$ & $\begin{array}{c}45 \\
\text { DAS }\end{array}$ & $\begin{array}{c}60 \\
\text { DAS }\end{array}$ & $\begin{array}{c}75 \\
\text { DAS }\end{array}$ & $\begin{array}{c}45 \\
\text { DAS }\end{array}$ & $\begin{array}{c}60 \\
\text { DAS }\end{array}$ & $\begin{array}{c}75 \\
\text { DAS }\end{array}$ \\
\hline To & 22.68 & 25.09 & 24.78 & 5.07 & 6.02 & 6.20 & 2.60 & 2.76 & 2.99 \\
\hline $\mathrm{T} 1$ & 25.88 & 27.55 & 27.02 & 5.40 & 5.35 & 6.00 & 2.39 & 3.01 & 3.22 \\
\hline $\mathrm{T} 2$ & 29.22 & 29.54 & 28.90 & 5.54 & 5.40 & 6.00 & 2.94 & 3.12 & 3.32 \\
\hline T3 & 25.96 & 27.36 & 25.59 & 5.52 & 5.27 & 7.50 & 2.79 & 2.99 & 3.19 \\
\hline LSD & 5.608 & 5.090 & 5.343 & 0.628 & 0.809 & 1.033 & 0.883 & 0.749 & 0.723 \\
\hline \multicolumn{10}{|l|}{ Variety } \\
\hline$V_{1}$ & 27.15 & 27.83 & 27.34 & 5.48 & 5.43 & 41.00 & 2.65 & 3.05 & 3.27 \\
\hline $\mathrm{V} 2$ & 24.72 & 26.94 & 25.80 & 5.28 & 5.59 & 5.00 & 2.71 & 2.89 & 3.09 \\
\hline LSD & 3.966 & 3.599 & 3.778 & 0.444 & 0.572 & 73.0 & 0.624 & 0.530 & 0.511 \\
\hline \multicolumn{10}{|l|}{ INT } \\
\hline To $\times V_{1}$ & 23.46 & 24.53 & 24.52 & 5.33 & 5.54 & 6.00 & 2.59 & 2.78 & 2.97 \\
\hline $\mathrm{To} \times \mathrm{V} 2$ & 21.90 & 25.65 & 25.05 & 4.80 & 6.50 & 6.00 & 2.61 & 2.75 & 3.00 \\
\hline $\mathrm{T} 1 \times \mathrm{V} 1$ & 27.04 & 27.60 & 28.18 & 5.50 & 5.58 & 6.00 & 1.99 & 3.02 & 3.28 \\
\hline $\mathrm{T} 1 \times \mathrm{V} 2$ & 24.72 & 27.51 & 25.85 & 5.29 & 5.12 & 5.00 & 2.80 & 3.00 & 3.17 \\
\hline $\mathrm{T} 2 \times \mathrm{V} 1$ & 30.34 & 30.41 & 30.17 & 5.50 & 5.71 & 6.00 & 3.00 & 3.20 & 3.40 \\
\hline $\mathrm{T} 2 \times \mathrm{V} 2$ & 28.10 & 28.67 & 27.63 & 5.58 & 5.08 & 5.00 & 2.88 & 3.05 & 3.25 \\
\hline $\mathrm{T} 3 \times \mathrm{V} 1$ & 27.75 & 28.79 & 26.49 & 5.58 & 4.88 & 146. & 3.2 & 3.23 & 3.42 \\
\hline $\mathrm{T} 3 \times \mathrm{V} 2$ & 24.16 & 25.94 & 24.68 & 5.46 & 5.67 & 5.00 & 2.56 & 2.76 & 2.96 \\
\hline LSD & 7.931 & 7.199 & 7.556 & 0.888 & 1.144 & 146.0 & 1.249 & 1.059 & 1.022 \\
\hline
\end{tabular}

Note: TRT $=$ Treatment, $\mathrm{PH}=$ Plant height, $\mathrm{LN}=$ leaf number, $\mathrm{PG}=$ Plant girth, $\mathrm{LSD}=$ Least significant difference, INT=Interaction

Table 6. Main effects and interactions of wood ash rates and variety on yield parameters of Carrot (Daucus carota) for bed experiment.

\begin{tabular}{|c|c|c|c|c|c|c|c|c|c|}
\hline TRT & H I & LFW & MY & NOHR & RD & RFW & RL & RU & TMY \\
\hline W-ASH & $\%$ & $\mathbf{G}$ & tones /ha & & $\mathbf{c m}$ & G & $\mathrm{Cm}$ & $\%$ & $\%$ \\
\hline To & 30.8 & 20.3 & 0.000024 & 3.00 & 1.24 & 8.5 & 15.5 & 54.2 & 3.57 \\
\hline $\mathrm{T} 1$ & $\begin{array}{l}52.7 \\
\end{array}$ & 27.3 & 0.000059 & 2.38 & 1.60 & 28.2 & 19.0 & 68.8 & 2.83 \\
\hline $\mathrm{T} 2$ & 51.3 & 48.1 & 0.000121 & 2.75 & 1.84 & 51.5 & 22.4 & 70.8 & 3.27 \\
\hline T3 & 47.0 & 60.6 & 0.000136 & 2.71 & 2.41 & 53.5 & 23.2 & 54.0 & 3.22 \\
\hline LSD & 20.02 & 20.47 & 0.0000722 & 0.681 & 0.716 & 22.02 & 6.44 & 22.87 & 0.810 \\
\hline \multicolumn{10}{|l|}{ Variety } \\
\hline V1 & 47.0 & 42.6 & 0.000113 & 2.75 & 2.06 & 38.9 & 22.0 & 58.3 & 3.27 \\
\hline $\mathrm{V} 2$ & 43.9 & 35.5 & 0.000057 & 2.67 & 1.49 & 31.9 & 18.1 & 65.6 & 3.17 \\
\hline LSD & 14.16 & 14.47 & 0.0000510 & 0.481 & 0.506 & 15.57 & 4.55 & 16.17 & 0.573 \\
\hline \multicolumn{10}{|l|}{ INT } \\
\hline $\mathrm{To} \times \mathrm{V} 1$ & 32.4 & 14.3 & 0.000021 & 3.00 & 1.25 & 8.1 & 15.9 & 50.0 & 3.57 \\
\hline $\mathrm{To} \times \mathrm{V} 2$ & 29.1 & 26.3 & 0.000026 & 3.00 & 1.23 & 8.9 & 15.1 & 58.3 & 3.57 \\
\hline $\mathrm{T} 1 \times \mathrm{V}_{1}$ & 60.4 & 26.4 & 0.000088 & 2.00 & 1.71 & 28.0 & 18.6 & 75.0 & 2.38 \\
\hline $\mathrm{T} 1 \times \mathrm{V}_{2}$ & 45.0 & 28.1 & 0.000030 & 2.75 & 1.48 & 28.5 & 19.4 & 62.5 & 3.27 \\
\hline $\mathrm{T} 2 \times \mathrm{V}_{1}$ & 48.8 & 53.8 & 0.000150 & 3.00 & 2.26 & 51.2 & 26.6 & 58.3 & 3.57 \\
\hline $\mathrm{T} 2 \times \mathrm{V} 2$ & 53.8 & 42.3 & 0.000092 & 2.50 & 1.43 & 51.9 & 18.2 & 83.3 & 2.97 \\
\hline $\mathrm{T} 3 \times \mathrm{V} 1$ & 46.2 & 75.9 & 0.000191 & 3.00 & 3.01 & 68.4 & 26.9 & 50.0 & 3.57 \\
\hline $\mathrm{T} 3 \times \mathrm{V} 2$ & 47.7 & 45.4 & 0.000081 & 2.42 & 1.81 & 38.5 & 19.6 & 58.1 & 2.88 \\
\hline LSD & 28.31 & 28.95 & 0.0001021 & 0.963 & 1.012 & 31.15 & 9.10 & 32.35 & 1.146 \\
\hline
\end{tabular}

Note: H I= Harvest Index, LFW= Leaf fresh Weight, MY=Marketable Yield, NOHR=Number of Harvested roots, R D=Root diameter, RFW=Root Fresh

Weight, RL=Root length, RU=Root Uniformity, TMY=Total Marketable Yield.

The result of the current study revealed that the application of $0.3 \mathrm{t} /$ ha of wood ash enhanced the following yield parameters: harvest index, marketable yield, root diameter, leaf fresh weight, root length, root fresh weight, total yield and whole plant biomass. This is in line with the work of Silva Dias [5] who stated that there is an increase in root yield, marketable yield in carrot root, juice concentration and total titratable acidity of root juice with increase in organic manure rates. The genotypes were significantly similar on the number of harvested roots for the pot and bed experiment. This was also stated by Aarssen [24] in his hypothesis that all variations of the competitive abilities 
among genotypes do not differ sufficiently among coexisting species to cause any competitive exclusion at the community level.

\subsubsection{Pot Experiment}

Table 7 showed the results of wood ash and variety effects on yield parameters of pot experiment. The parameters measured showed no significant in almost all the parameters. The parameters having no significant effect on the pot experiment could probably be as a result of environmental factors being almost homogeneous that is, same quantity of sand, water, same size of pot and only wood ash rates and carrot varieties were varied. This also means that the wood ash does not have any significance effect on the performance of carrot in the pot experiment. However, the combination of $0.2 \mathrm{t} / \mathrm{ha}$ of wood ash and carotte touchon varieties enhanced plant height, harvest index, leaf fresh weight, marketable yield, root diameter, root fresh weight, root length and total yield in the pot experiment. Also the combination $0.3 \mathrm{t} /$ ha of wood ash and carotte touchon variety significantly enhanced the yield parameters of carrot in the bed experiment such as leaf fresh weight, marketable yield, root diameter, root fresh weight, marketable yield, root diameter, root length, total yield and whole plant biomass. This finding is in agreement with the report by Ojeniyi, et al. [25] which stated that addition of ash to tilled and non-tilled soil increased cassava growth.

Table 7. Main effects and interactions of wood ash rates and carrot varieties on yield parameters of carrot (Daucus carota) for the pot experiment.

\begin{tabular}{l|c|c|c|c|c|c|c|c}
\hline TRT & HI & LFW & MY & NOHR & RD & RFW & RL & RU \\
\hline W-Ash & $\mathbf{\%}$ & $\mathbf{g}$ & tones $/ \mathbf{h a}$ & & $\mathbf{c m}$ & $\mathbf{G}$ & $\mathbf{c m}$ & \% \\
\hline To & 61.2 & 3.23 & 0.000028 & 5.875 & 1.513 & 6.5 & 10.75 & 29.2 \\
\hline $\mathrm{T} 1$ & 62.1 & 4.37 & 0.000033 & 6.000 & 1.723 & 7.4 & 10.61 & 33.3 \\
\hline $\mathrm{T} 2$ & 67.9 & 4.98 & 0.000086 & 6.000 & 1.871 & 12.6 & 11.00 & 25.0 \\
\hline $\mathrm{T} 3$ & 63.9 & 3.79 & 0.000030 & 6.000 & 1.646 & 8.5 & 9.13 & 33.3 \\
\hline LSD & 8.56 & 2.635 & 0.0000617 & 0.1838 & 0.4868 & 6.33 & 3.748 & 13.28 \\
\hline
\end{tabular}

\begin{tabular}{|c|c|c|c|c|c|c|c|c|}
\hline \multicolumn{9}{|l|}{ Variety } \\
\hline $\mathrm{V} 1$ & 64.8 & 4.34 & 0.000059 & 6.000 & 1.738 & 9.6 & 10.45 & 32.3 \\
\hline $\mathrm{V} 2$ & 62.8 & 3.85 & 0.000030 & 5.938 & 1.639 & 7.9 & 10.29 & 28.1 \\
\hline $\mathrm{LSD}$ & 6.05 & 1.863 & 0.0000436 & 0.1300 & 0.3442 & 4.47 & 2.650 & 9.39 \\
\hline \multicolumn{9}{|l|}{ INT } \\
\hline $\mathrm{To} \times \mathrm{V} 1$ & 62.9 & 2.87 & 0.000030 & 6.000 & 1.625 & 7.5 & 10.87 & 25.0 \\
\hline $\mathrm{To} \times \mathrm{V} 2$ & 59.5 & 3.59 & 0.000026 & 5.750 & 1.400 & 5.6 & 10.63 & 33.3 \\
\hline $\mathrm{T} 1 \times \mathrm{V} 1$ & 60.7 & 5.17 & 0.000034 & 6.000 & 1.665 & 6.9 & 10.76 & 37.5 \\
\hline $\mathrm{T} 1 \times \mathrm{V}_{2}$ & 63.5 & 3.58 & 0.000031 & 6.000 & 1.780 & 7.9 & 10.46 & 29.2 \\
\hline $\mathrm{T} 2 \times \mathrm{V} 1$ & 71.7 & 6.09 & 0.000150 & 6.000 & 2.063 & 17.1 & 12.23 & 25.0 \\
\hline $\mathrm{T} 2 \times \mathrm{V}_{2}$ & 64.2 & 3.88 & 0.000023 & 6.000 & 1.680 & 8.1 & 9.77 & 25.0 \\
\hline $\mathrm{T} 3 \times \mathrm{V} 1$ & 63.9 & 3.25 & 0.000021 & 6.000 & 1.598 & 7.0 & 7.95 & 41.6 \\
\hline $\mathrm{T} 3 \times \mathrm{V} 2$ & 63.9 & 4.33 & 0.000039 & 6.000 & 1.695 & 10.0 & 10.31 & 25.0 \\
\hline $\mathrm{LSD}$ & 12.10 & 3.726 & 0.0000872 & 0.2600 & 0.6884 & 8.95 & 5.301 & 18.79 \\
\hline
\end{tabular}

Note: TRT $=$ Treatment, $\mathrm{LFW}=$ Leaf fresh weight, $\mathrm{MY}=$ Marketable yield, NOHR $=$ Number of harvested roots per bed, $\mathrm{RD}=$
Root diameter, HI= Harvest Index, RFW= Root fresh weight, RL=Root length, RU=Root uniformity, LSD= Least significance difference.

\section{CONCLUSION}

Considering the overall result, the combination $0.3 \mathrm{t} / \mathrm{ha}$ of wood ash and carotte touchon variety was the best option for carrot yield of bed experiment while the combination $0.2 \mathrm{t} / \mathrm{ha}$ of wood ash and carotte touchon variety to an extent was the best option for carrot yield of pot experiment.

To obtain maximum yield for carrot production, carrot seeds should be grown on beds and not on pots. Carotte touchon variety should be used and $0.3 \mathrm{t} / \mathrm{ha}$ of wood ash should be applied. If pots are to be used, $0.2 \mathrm{t} / \mathrm{ha}$ of wood ash should be applied. 
Funding: This study received no specific financial support.

Competing Interests: The authors declare that they have no competing interests.

Authors' Contributions: All authors contributed equally to the conception and design of the study.

\section{REFERENCES}

[1] F. Que, X.-L. Hou, G.-L. Wang, Z.-S. Xu, G.-F. Tan, T. Li, Y.-H. Wang, A. Khadr, and A.-S. Xiong, "Advances in research on the carrot, an important root vegetable in the Apiaceae family," Horticulture Research, vol. 6, pp. 1-15, 2019.Available at: https://doi.org/10.1038/s41438-019-0150-6.

[2] L. W. Jett, "Growing beets and carrots within high tunnels," Extension Service West Virginia University Commercial Horticulture Specialist 2102 Agriculture Building Morgantown, WV 26506 Pp 1-4 20112011.

[3] D. J. C. Silva, "Nutritional and health benefits of carrots and their seed extracts," Food and Nutrition Sciences, vol. 5, pp. 2147-2 156, 2014.Available at: http://dx.doi.org/10.4236/fns.2014.522227.

[4] J. S. Dias, "Major classes of phytonutriceuticals in vegetables and health benefits: A review," Journal of Nutritional Therapeutics, vol. 1, pp. 31-62, 2012.Available at: https://doi.org/10.6000/1929-5634.2012.01.01.5.

[5] J. C. Silva Dias, "Nutritional benefits of carrot and their seed extracts," Food and Nutrition Sciences, vol. 5, pp. $2147-2156$, 2014.Available at: https://doi.org/10.4236/fns.2014.522227.

[6] S. Pugliese, T. Jones, M. D. Preston, P. Hazlett, H. Tran, and N. Basiliko, "Wood ash as a forest soil amendment: The role of boiler and soil type on soil property response," Canadian Journal of Soil Science, vol. 94, pp. 62 1-634, 2014.Available at: https://doi.org/10.4141/cjss-2014-037.

[7] N. Lupwayi, M. Arshad, R. Azooz, and Y. Soon, "Soil microbial response to wood ash or lime applied to annual crops and perennial grass in an acid soil of northwestern Alberta," Canadian Journal of Soil Science, vol. 89, pp. 169-177, 2009.

[8] L. L. Win, "Agronomic characteristics and nutritional quality of carrot (Daucus carota L.) cultivars from Myanmar and Germany as affected by mineral and organic fertilizers," Ph.D Thesis, Faculty of Agricultural Science, Georg-AugustUniversity Göttingen, Germany, 2010.

[9] F. Adekayode and M. Olojugba, "The utilization of wood ash as manure to reduce the use of mineral fertilizer for improved performance of maize (Zea mays L.) as measured in the chlorophyll content and grain yield," Journal of Soil Science and Environmental Management, vol. 1, pp. 40-45, 2010.

[10] J. Aditi, "Leaves from nitrogen-rich trees can be potential fertilizers.India Science Wire. Retrieved from; https://www.researchstash.com/2018/04/19/leaves-from-nitrogen-rich-trees-can-be-potential-fertilizers/2018," 2018.

[11] J. Wiklund, "Effects of wood ash on soil fertility and plant performance in southwestern Kenya," Examenasarbeten, Institutionen for Mark Ochmilijo, SLU, vol. 16, pp. 34-40, 2017.

[12] M. Akinola, S. Ojeniyi, and O. Amusan, "Soil chemical composition and soybean yield as influenced by tillage and ash," Nigerian Journal of Soil Science, vol. 22, pp. 24-28, 2013.

[13] A. Soretire and A. Olayinka, "Response of soybean (Glycine max L.) to cow dung and wood ash application in tropical acid soils of South-Western Nigeria," Nigerian Journal of Soil Science, vol. 23, pp. 103-113, 2013.

[14] S. O. Ojeniyi, A. Adejuwon, and M. I. Abdulraheem, "Soil Physico-chemical properties and cassava yield in alfisol given tillage ash treatments," Nigerian Journal of Soil Science (Special), vol. 25, pp. 71-82, 2015.

[15] B. Ewulo, O. Babadele, and S. Ojeniyi, "Sawdust ash and urea effect on soil and plant nutrient content and yield of tomato," American-Eurasian Journal of Sustainable Agriculture, vol. 3, pp. 88-92, 2009.

[16] J. C. Obiefuna, I. Ibeawuchi, E. A. Ekong, N. A. Okoli, and R. A. Alagba, "Liming efficiency of organic and inorganic limes for acid soil amelioration and production of groundnut in Tropical rainforest - ultisols of Southeastern Nigeria," in Proceedings of the 8th Annual Conference on Organic Agriculture University of Calabar, 2012, pp. 18-22.

[17] S. O. Ojeniyi, O. P. Oso, and A. A. Arotolu, "Response of vegetables to wood ash fertilizer," in Proceedings of the 35th Annual Conference of Agricultural Society of Nigeria, UNAAB, 2002, pp. 39-43. 
[18] S. K. Yadav, U. V. Khokar, and R. P. Yadav, "Integrated nutrient management for strawberry cultivation," Indian Journal of Horticulture, vol. 67, pp. 445-449, 2010.

[19] R. Ajala, M. Awodun, and S. Oladele, "Effects of wood ash biomass application on growth indices and chlorophyll content of maize and lima bean intercrop," Turkish Journal of Agriculture-Food Science and Technology, vol. 5, pp. 614-621, 2017.Available at: https://doi.org/10.24925/turjaf.v5i6.614-621.1093.

[20] S. Shrawan, P. K. Yadav, and B. Singh, "Effect of nitrogen and potassium on growthand yield of onion (Alliumcepa L.) cv. PusaRed," Haryana Journal of Horticultural Sciences, vol. 33, pp. 308-309, 2004.

[21] C. N. Mbah and D. Nkpaji, "Response of maize (Zea mays L.) to different rates of wood-ash application in acid ultisol in Southeast Nigeria," The Journal of American Science, vol. 5, pp. 53 - 57, 2009.

[22] D. O. Babadele, S. O. Ojeniyi, and O. O. Agbede, "Periodic nutrient content of cassava as influenced by sawdust ash and siam weed residue," in Proceedings 37th Annual Conference of Soil Science Society of Nigeria, Lafia, 2013a, pp. 133-140.

[23] M. Awodun and S. Ojeniyi, "Response of ground nut yield and nutrient status totillage and wood ash," Nigeria Agricultural Journal, vol. 36, pp. 80-87, 2005.Available at: https://doi.org/10.4314/naj.v36i1.3209.

[24] L. Aarssen, "Causes and consequences of variation in competitive ability in plant communities," Journal of Vegetation Science, vol. 3, pp. 165-174, 1992.Available at: https://doi.org/10.2307/3235677.

[25] S. Ojeniyi, A. Oyatoye, and M. Abdulraheem, "Use of ash for soil fertility improvement effect on cowpea," Nigeria Journal of Soil Science, vol. 27, pp. 216-221, 2017.

Views and opinions expressed in this article are the views and opinions of the author(s), Current Research in Agricultural Sciences shall not be responsible or answerable for any loss, damage or liability etc. caused in relation to/arising out of the use of the content. 